University of Nebraska - Lincoln

DigitalCommons@University of Nebraska - Lincoln

USDA National Wildlife Research Center - Staff Publications
U.S. Department of Agriculture: Animal and Plant Health Inspection Service

January 2001

\title{
Ecotoxicological Risks of Potential Toxicants for Brown Tree Snake Control on Guam
}

John J. Johnston

APHIS/WS/National Wildlife Research Center, U.S. Department of Agriculture

Richard E. Mauldin

APHIS/WS/National Wildlife Research Center, U.S. Department of Agriculture

Peter J. Savarie

APHIS/WS/National Wildlife Research Center, U.S. Department of Agriculture

Joseph E. Brooks

APHIS/WS/National Wildlife Research Center, U.S. Department of Agriculture

Thomas M. Primus

APHIS/WS/National Wildlife Research Center, U.S. Department of Agriculture

Follow this and additional works at: https://digitalcommons.unl.edu/icwdm_usdanwrc

Part of the Environmental Sciences Commons

Johnston, John J.; Mauldin, Richard E.; Savarie, Peter J.; Brooks, Joseph E.; and Primus, Thomas M., "Ecotoxicological Risks of Potential Toxicants for Brown Tree Snake Control on Guam" (2001). USDA National Wildlife Research Center - Staff Publications. 590.

https://digitalcommons.unl.edu/icwdm_usdanwrc/590

This Article is brought to you for free and open access by the U.S. Department of Agriculture: Animal and Plant Health Inspection Service at DigitalCommons@University of Nebraska - Lincoln. It has been accepted for inclusion in USDA National Wildlife Research Center - Staff Publications by an authorized administrator of DigitalCommons@University of Nebraska - Lincoln. 
Published in Pesticides and Wildlife, edited by John J. Johnston. ACS Symposium Series 771. American Chemical Society, Washington, DC, 2001. 


\section{Chapter 16}

\section{Ecotoxicological Risks of Potential Toxicants for Brown Tree Snake Control on Guam}

\section{John J. Johnston, Richard E. Mauldin, Pete J. Savarie, Joseph E. Brooks,} and Thomas M. Primus

\section{APHIS/WS/National Wildlife Research Center, U.S. Department of Agriculture, 4101 LaPorte Avenue, Fort Collins, CO 80521-2154}

\section{INTRODUCTION}

The brown tree snake (Boiga irregularis) is a nocturnal, arboreal, rear-fanged, mildly venomous, colubrid snake which can reach lengths of up to $2.3 \mathrm{~m}$ and weigh as much as $2 \mathrm{~kg}(1)$. Originally, the species' range included the northern and eastern coasts of Australia, Papua New Guinea and nearby islands (2). It is believed that sometime in the 1950's, that snakes were inadvertently transported from New Guinea to Guam, where they proliferated (3). By the mid-1960's, marked decreases in Guam's bird life were observed. By the mid-1980's, snake densities were estimated at 50 to $100 /$ hectare $(13,000$ to 26,000 /sq mile), higher densities than those recorded for any other snake $(3,4)$.

Brown tree snakes are dietary generalists, being observed to eat chicken bones, cooked spare ribs, lizards, birds, rodents, domestic fowl hatchlings, puppies, piglets, rabbits (in hutches), and pet birds (in cages inside homes) $(1,5)$. Human infants have also been attacked, resulting in very serious bites $(6,7)$. Snake predation has resulted in the extirpation or severe reduction in the populations of virtually all Guam's avifauna and has essentially resulted in the extinction of four endemic species/subspecies: 1) Bridled white-eye (Zosterops conspicillatus conspicillatus), 2) Guam flycatcher (Myiagra freycineti), 3) Micronesian kingfisher (Halcyon cinnamomina cinnamomina), and 4) Rufous fantail (Rhipidura rufifrons uraniae) $(8,9)$. The Mariana crow (Corvus kubaryi) has also been severely reduced, with 8 birds remaining on Guam, and an additional 300 to 600 remaining on the nearby island of Rota (10). The crow is listed as an endangered species and, as a scavenger that might consume lethally-dosed snake carcasses resulting from chemical toxicant control operations, plays a significant role in secondary hazard assessments of the use of such toxicants.
In addition to the ecological and agricultural damage, snakes crawl along power lines in search of prey. This activity frequently results in short circuits leading to extensive damage to power transmission equipment, subsequent power blackouts to human population centers, and millions of dollars in economic losses (7).

The large military presence on Guam and shipment of associated cargo coupled with the high snake densities increase the likelihood of dispersal of the snake to other locations where the whole damage scenario might be repeated. Individual snakes have been observed on other islands in the Marianas (Saipan, Tinian) and other islands such as Kwajalein, Wake, Diego Garcia, and Hawaii $(11,7)$. One individual was found in a cargo container in Corpus Christi, TX which had been shipped from Guam some six months earlier (12). The United States Department of Agriculture Wildlife Services personnel on Guam utilize a variety of measures to prevent snake accidental snake relocations, but the only long term solution is the reduction or eradication of the brown tree snake population on Guam. As part of a multiagency snake control program funded by the U.S. Department of Defense's Legacy Program scientists from the NWRC were asked to evaluate traps, lures and chemical toxicants. Several candidate compounds with demonstrated toxicity to poikilothermous vertebrates were screened for effectiveness. Among the most effective were: 1) pyrethrum, an extract of Chrysanthemum flowers containing a family of six pyrethrins that is registered with the U.S. EPA for insecticidal use, 2) rotenone, a natural product extracted primarily from roots of the tropical plant genus Derris, registered as both a piscicide and insecticide, and 3) propoxur, a carbamate insecticide.

\section{EXPERIMENTAL}

\section{Toxicity Testing}

On Guam, the acute toxicity of toxicants to brown tree snakes was evaluated by oral gavage, oral dosing in bait, and dermal application. For oral gavage, the toxicants were dissolved in propylene glycol or ethanol and introduced directly into the entrance of the snake's esophagus by means of a ball tipped feeding needle (13). As future wide scale snake population reduction might utilize a baiting program, snake preferences for various potential bait matrices were evaluated (14). Of 21 bait matrices tested, geckos and mice, processed meat (SPAM) and juvenile quail were well accepted. These latter matrices were subsequently combined with each toxicant at varying concentrations and offered to snakes. Lastly, toxicants dissolved in ethanol were applied to the dorsal surface of restrained snakes using a syringe fitted with a ball tipped needle. In all procedures, five snakes were used to test each toxicant concentration. During experimentation, snakes were housed in plastic cages in racks kept outdoors under shadecloth. Snakes which received non-lethal toxicant doses 
were euthanized using halothane (14). All snakes were wrapped in aluminum foil and frozen for subsequent residue determination.

\section{Analytical Chemistry}

Chemical analyses were required to generate the data required for risk assessments. Residues of the toxicants in snakes following dosing were determined. To determine the potential secondary hazards associated with the use of these potential snake toxicants, residue methods were developed to quantify rotenone, pyrethrins and propoxur in whole body brown tree snakes. For all three methods, frozen $\left(-20^{\circ} \mathrm{C}\right)$ snakes were cut into 2 inch pieces and placed into a cylindrical stainless steel container containing liquid nitrogen. The frozen snake was then shattered into a homogeneous powder with a steel bar (15)

To quantify propoxur residues, a silica gel matrix solid phase dispersion method was developed to clean up and concentrate the residues in $2 \mathrm{~g}$ portions of homogenized tissue. Extracts were analyzed by reversed phase high performance liquid chromatography (HPLC) with fluorescence detection (excitation $=225 \mathrm{~nm}$, emission $=305 \mathrm{~nm}$ ). The mean recovery and standard deviation (std dev) were 86.7 and 7.8 percent, respectively. The method limit of detection (MLOD) was 9 parts per billion (ppb) (16).

To quantify pyrethrins, a liquid extraction followed by $\mathrm{C} 8$ solid phase extraction clean up was developed to clean up and concentrate pyrethrins in $6 \mathrm{~g}$ portions of homogenized tissue. Extracts were analyzed by gas chromatography (GC)/electron capture detection (ECD). Mean recovery was $70.8 \%$ with a std dev of $5.7 \%$. MLOD was $6.5 \mathrm{ng} / \mathrm{g}(17)$

To quantify rotenone residues, a silica/florisil solid phase extraction method was developed to clean up and concentrate rotenone residues in $2 \mathrm{~g}$ portions of homogenized tissue. Rotenone residues in the extracts were separated by HPLC and quantified by ultraviolet detection at $295 \mathrm{~nm}$. Mean recovery was $84.7 \%$ with a std $\operatorname{dev}$ of $7.4 \%$. MLOD was $0.012 \mu \mathrm{g} / \mathrm{g}$ (18).

\section{RESULTS}

\section{Toxicity testing}

\section{Pyrethrins}

Snakes were gavaged with pyrethrum solutions in ethanol and propylene glycol (Table I). Doses ranged from 5 to $40 \mathrm{mg} / \mathrm{kg}$. Oral gavage with pyrethrins yielded $100 \%$ mortality only at the highest tested dose of $40 \mathrm{mg} / \mathrm{kg}$. This dose is equivalent to a dose of approximately 0.25 to $8 \mathrm{mg}$ active ingredients per snake for average snakes ranging in weight from 50 to $200 \mathrm{~g}$. No mortality was found in controls given ethanol or propylene glycol only.

Table I. Mortality Following Gavage with Pyrethrum

\begin{tabular}{|c|c|c|c|c|}
\hline \multirow[b]{2}{*}{ Carrier } & \multicolumn{4}{|c|}{ Dose $(\mathrm{mg} / \mathrm{kg})$} \\
\hline & 5 & 10 & 20 & 40 \\
\hline Ethanol & $\mathrm{ND}^{*}$ & $1 / 5^{* *}$ & $4 / 5$ & $5 / 5$ \\
\hline Propylene glycol & $0 / 5$ & $4 / 5$ & $3 / 5$ & $5 / 5$ \\
\hline
\end{tabular}

Not determined

\#Dead/ \#tested

Source: Reference 13.

Incorporation of pyrethrum into SPAM and quail chick bait matrices greatly reduced toxicity (Table II). For example, when given in a treated bait, only $50 \%$ mortality was achieved at the highest dose of $40 \mathrm{mg} / \mathrm{bait}(40 \mathrm{mg} / \mathrm{snake})$. This is about 10 to 20 times greater dose than the highest dose administered by oral gavage (which produced $100 \%$ mortality). Obviously, combination with a bait severely attenuated the effectiveness of the pyrethrum.

Table II. Acute toxicity of pyrethrum fortified baits

\begin{tabular}{ccc}
\multicolumn{4}{c}{ Table 11. Acute toxicity of pyrethrum fortified baits } \\
\hline $\begin{array}{c}\text { Dose } \\
(\text { mg/bait })\end{array}$ & $\begin{array}{c}\text { Number of Snakes } \\
\text { Consuming Bait }\end{array}$ & $\begin{array}{c}\text { Percent } \\
\text { Mortality }\end{array}$ \\
\hline 20 & 5 & 20 \\
40 & 4 & 50 \\
\hline
\end{tabular}

Source: Reference 14.

The whole body pyrethrin residues in snakes given $40 \mathrm{mg}$ baits ranged from 4.1 to $501 \mu \mathrm{g} / \mathrm{g}$ (Table III). The higher residues were found in fatally dosed snakes. This suggests that snakes surviving the initial pyrethrin dose will rapidly metabolize/excrete the pyrethrins. Residue concentrations in surviving snakes were less than in fatally dosed snakes. Quantification of these residue levels was necessary to estimate the potential secondary hazards to predators and/or scavengers potentially feeding on pyrethrin- containing brown tree snake carcasses. For secondary hazard estimates, the highest residue concentrations for each toxicant was used. This conservative approach generally results in "worst case" risk assessment calculations. For pyrethrins, the concentration of $501 \mu \mathrm{g} / \mathrm{g}$ was used. 
Table III. Pyrethrin dose and residues

\begin{tabular}{cccc}
\hline \multicolumn{5}{c}{ Table III. Pyrethrin dose and residues } \\
$\begin{array}{c}\text { Bodyweight } \\
\text { (grams) }\end{array}$ & $\begin{array}{c}\text { Dose } \\
(\mathrm{mg} / \mathrm{kg})\end{array}$ & $\begin{array}{c}\text { Tissue Residue } \\
(\mu \mathrm{g} / \mathrm{g})\end{array}$ & Fate \\
\hline 121 & 331 & 113 & Died \\
83 & 482 & 501 & Died \\
206 & 194 & 29 & Survived \\
45 & 889 & 4.1 & Survived \\
\hline
\end{tabular}

Source: References 19,20 .

\section{Rotenone}

Snakes were also orally gavaged with varying doses of rotenone (Table IV). By this route of administration, rotenone appears to be more toxic than pyrethrins as the lowest dose that achieved $100 \%$ mortality was $2.5 \mathrm{mg} / \mathrm{kg}(0.125 \mathrm{mg}-0.50 \mathrm{mg} / \mathrm{snake})$ compared to $40 \mathrm{mg} / \mathrm{kg}$ for pyrethrins. All concentrations higher than $2.5 \mathrm{mg} / \mathrm{kg}$ also produce $100 \%$ mortality. Again, no mortality was noted in control snakes gavaged only with carrier.

Table IV. Acute Toxicity following gavage with rotenone

\begin{tabular}{lccccccc}
\hline $\begin{array}{l}\text { Dose } \\
(\mathrm{mg} / \mathrm{kg})\end{array}$ & 0.61 & 1.25 & 2.5 & 5 & 10 & 20 & 40 \\
$\begin{array}{l}\text { Mortality } \\
\text { (dead/treated) }\end{array}$ & $0 / 5$ & $1 / 5$ & $5 / 5$ & $5 / 5$ & $5 / 5$ & $5 / 5$ & $5 / 5$ \\
\hline
\end{tabular}

Source: Reference 13.

However, when rotenone was incorporated into SPAM and quail chick baits, no acute toxicity was observed at any concentrations tested (Table V). The highest concentration, $10 \mathrm{mg} / \mathrm{bait}$, was $40-80$ times the $2.5 \mathrm{mg} / \mathrm{kg}$ dose which yielded $100 \%$ mortality in the orally gavaged snakes. Incorporation of rotenone into baits decreased the toxicity to even a greater extent than was observed for pyrethrins.

Table V. Acute Toxicity of Rotenone Fortified Baits

\begin{tabular}{ccc}
\hline $\begin{array}{c}\text { Concentration } \\
(\text { mg/bait })\end{array}$ & $\begin{array}{c}\text { Number of Snakes } \\
\text { Consuming Bait }\end{array}$ & $\begin{array}{c}\text { Percent } \\
\text { Mortality }\end{array}$ \\
\hline 2.5 & 3 & 0 \\
5 & 5 & 0 \\
10 & 5 & 0 \\
\hline
\end{tabular}

Source: Reference 14
Whole body rotenone residues were determined in the snakes fed baits containing $10 \mathrm{mg}$ rotenone (Table VI). As all the snakes survived, the magnitude of residues were similar to those observed for the surviving pyrethrins dosed snakes and less than the fatally pyrethrins dosed snakes. The highest observed level was $61 \mu \mathrm{g} / \mathrm{g}$.

Table VI. Rotenone Dose and Residues

\begin{tabular}{cccc}
\hline $\begin{array}{c}\text { Bodyweight } \\
\text { (grams) }\end{array}$ & $\begin{array}{c}\text { Dose } \\
(\mathrm{mg} / \mathrm{kg})\end{array}$ & $\begin{array}{c}\text { Tissue Residue } \\
(\mu \mathrm{g} / \mathrm{g})\end{array}$ & Fate \\
\hline 111 & 90 & 61 & Survived \\
131 & 76 & 0.67 & Survived \\
185 & 54 & 12.4 & Survived \\
98 & 102 & 48.4 & Survived \\
\hline
\end{tabular}

Source: Reference 21

Propoxur

Brown tree snakes were orally gavaged with solutions containing varying concentrations of propoxur. The lowest concentration to yield $100 \%$ mortality was 40 $\mathrm{mg} / \mathrm{kg}$ which is equivalent to a dose of $2-8 \mathrm{mg}$ propoxur per snake.

Table VII. Acute Toxicity Following Gavage with

\begin{tabular}{lcccc} 
Propoxur & & & & \\
\hline $\begin{array}{l}\text { Dose } \\
(\mathrm{mg} / \mathrm{kg})\end{array}$ & 5 & 10 & 20 & 40 \\
$\begin{array}{l}\text { Mortality } \\
\text { (dead/treated) }\end{array}$ & $0 / 5$ & $2 / 5$ & $3 / 5$ & $5 / 5$ \\
\hline
\end{tabular}

Source: Reference 13.

Propoxur baits were prepared by fortifying quail chicks and SPAM at $20 \mathrm{mg} / \mathrm{bait}$ which delivered a dose ranging from $146-220 \mathrm{mg} / \mathrm{kg}$ ( $7-43 \mathrm{mg} / \mathrm{snake})$. While this dose is 4 to 5 times the $40 \mathrm{mg} / \mathrm{kg}$ oral gavage dose that resulted in $100 \%$ mortality, mortality was only $75 \%$. Again, incorporating the toxicant into a biological matrix reduced toxicity (Table VIII)

\begin{tabular}{ccc}
\multicolumn{3}{c}{ Table VIII. Acute Toxicity of Propoxur Fortified Baits } \\
\hline $\begin{array}{c}\text { Concentration } \\
(\text { mg/bait })\end{array}$ & $\begin{array}{c}\text { Number of Snakes } \\
\text { Consuming Bait }\end{array}$ & $\begin{array}{c}\text { Percent } \\
\text { Mortality }\end{array}$ \\
\hline 20 & 4 & 75 \\
\hline
\end{tabular}

Source: Reference 14. 
Propoxur residues in snakes consuming baits containing $20 \mathrm{mg}$ propoxur were similar for both surviving and fatally dosed snakes (Table IX). The highest observed residue was $141 \mu \mathrm{g} / \mathrm{g}$.

Table IX. Propoxur Residues in Snakes Fed Propoxur Baits

\begin{tabular}{cccc}
\hline $\begin{array}{c}\text { Bodyweight } \\
(\text { grams })\end{array}$ & $\begin{array}{c}\text { Dose } \\
(\mathrm{mg} / \mathrm{kg})\end{array}$ & $\begin{array}{c}\text { Tissue Residue } \\
(\mu \mathrm{g} / \mathrm{g})\end{array}$ & Fate \\
\hline 131 & 153 & 106 & Died \\
124 & 161 & 134 & Died \\
137 & 146 & 116 & Survived \\
91 & 220 & 141 & Died \\
\hline
\end{tabular}

Source: Reference 22,23.

Dermal application was evaluated as a potential mean of applying toxicants to snakes. By far the most effective compound tested was rotenone, yielding $100 \%$ mortality at $10 \mathrm{mg} / \mathrm{kg}$, or 0.5 to $2 \mathrm{mg} /$ snake (Table X). This level of toxicity was half that observed for administration via oral gavage.

Table X. Acute toxicity* Following Dermal Dosing

\begin{tabular}{lccccccc}
\hline \multicolumn{7}{c}{ Table X. Acute toxicity* Following Dermal Dosing } \\
Toxicant & 0 & 2.5 & 5 & 10 & 20 & 40 & 80 \\
\hline Pyrethrins & $-* *$ & - & - & - & $1 / 5$ & $2 / 5$ & - \\
Rotenone & - & $0 / 5$ & $2 / 5$ & $5 / 5$ & $5 / 5$ & $5 / 5$ & $5 / 5$ \\
Propoxur & - & - & - & - & $0 / 5$ & $3 / 5$ & $2 / 5$ \\
\hline
\end{tabular}

Note: * \# dead/\#tested, $* *$ Not determined

Source: Reference 13.

Table XI. Residues and Acute Toxicity Following Dermal Application of Rotenone

\begin{tabular}{ccccccc}
\hline \multicolumn{7}{c}{ Dose $(\mathrm{mg} / \mathrm{kg})$} \\
& 2.5 & 5 & 10 & 20 & 40 & 80 \\
\hline & $0.221(\mathrm{~s})$ & $0.390(\mathrm{~s})$ & $4.07(\mathrm{~d})$ & $6.84(\mathrm{~d})$ & $11.1(\mathrm{~d})$ & $35.2(\mathrm{~d})$ \\
& $0.183(\mathrm{~s})$ & $0.579(\mathrm{~s})$ & $3.04(\mathrm{~d})$ & $7.76(\mathrm{~d})$ & $14.4(\mathrm{~d})$ & $17.2(\mathrm{~d})$ \\
Residue & $0.112(\mathrm{~s})$ & $1.70(\mathrm{~d})$ & $4.74(\mathrm{~d})$ & $8.94(\mathrm{~d})$ & $13.5(\mathrm{~d})$ & $23.3(\mathrm{~d})$ \\
$(\mu \mathrm{g} / \mathrm{g})$ & - & $1.72(\mathrm{~d})$ & - & - & $18.2(\mathrm{~d})$ & - \\
& - & - & - & - & $16.0(\mathrm{~d})$ & - \\
\hline Mean & 0.172 & 1.1 & 3.95 & 7.85 & 14.6 & 25.2 \\
residue & 0.05 & 0.71 & 0.86 & 1.05 & 2.7 & 9.2 \\
Std. dev. & 0.86
\end{tabular}

Note: $(\mathrm{s})=$ survived $(\mathrm{d})=$ died

Source: Reference 22.
As rotenone was the only toxicant that appeared to be promising with respect to dermal application, the residue and toxicity data in Table XI is limited to snakes dermally dosed with rotenone. Using the minimum $100 \%$ lethal dosage of $10 \mathrm{mg} / \mathrm{kg}$, the highest tissue concentration found was $4.74 \mu \mathrm{g} / \mathrm{g}$.

\section{Secondary hazard assessment}

When evaluating the use of chemical toxicants to control snake populations, consideration must be given to those non-target species which could accidentally ingest toxicant by scavenging or preying on dead or dying snakes. On Guam such scavengers include feral cats, wild pigs, feral dogs, monitor lizards (Varanus indicus), and the Mariana crow. Obviously, the endangered crow elicits the greatest concern from a secondary hazard standpoint, while the other scavenger species are introduced and may be considered pest species themselves. Ideally, secondary hazard considerations should not be limited to non-target species found on Guam. Toxicants developed for brown tree snakes may be required to control future introduced brown tree snake populations at other locations. These locations will likely contain a wider variety of potential non-target species than are currently found on Guam. Also, the brown tree snake population on Guam may be suitably reduced to permit the reintroduction of other species such as the Micronesian kingfisher, which may have preyed on small snakes $(6,24)$. In this scenario, where regular chemical control may be required to keep snake populations minimized, the reintroduced species represent potential non-target species.

A widely used, straight forward approach for estimating non target hazards is the risk quotient (RQ) method (25). The RQ is the expected dose or dietary concentration divided by the dose or concentration expected to produce lethality in $50 \%$ of the population, respectively (dose/LD $\mathrm{L}_{50}$ or concentration/LC $\mathrm{C}_{50}$ ). $\mathrm{RQs}$ provide a numerical basis for decision making. A RQ greater than 1 indicates that there are appreciable non target risks associated with use of this chemical. A RQ less than 1 indicates that the non target risks from use of this chemical may be acceptable under approved usage guidelines. To provide a "worst case" estimate of non target hazards, we assumed that $100 \%$ of the exposed animal's diet would consist of the pesticide formulation (primary hazard) or the tissue, organ, or carcass (secondary hazard) containing the residue highest concentration. EPA further breaks-down RQ values less than 1 into the following categories (26):

For the potential brown tree snake toxicants, RQs were calculated for the crow, dog, pig and cat. Crows, feral dogs and feral cats are potential consumers of brown tree snake carcasses on Guam. For pyrethrin bait-dosed snakes, the highest tissue residue concentration of $501 \mu \mathrm{g} / \mathrm{g}$ was used for all calculations. For a worst case exposure estimate, this concentration was multiplied by the average food consumption for crows, $0.076 \mathrm{~g}$ food/g bodyweight/day (27). To estimate the acute toxicity of pyrethrins to crows, we relied on the literature value of $7070 \mu \mathrm{g} / \mathrm{g}$, the $\mathrm{LD}_{50}$ for Japanese quail. The resulting RQ for crows consuming brown tree snakes killed by 
Table XIII. Pyrethrum Risk Quotients

\begin{tabular}{llc}
\hline Animal & \multicolumn{1}{c}{ Calculation } & $R Q$ \\
\hline Crow & $\frac{501 \mu \mathrm{g} / \mathrm{g} \times 0.076 \mathrm{~g} / \mathrm{g}}{7070 \mu \mathrm{g} / \mathrm{g}}=0.002$ \\
Dog & $\frac{501 \mu \mathrm{g} / \mathrm{g} \times 0.006 \mathrm{~g} / \mathrm{g}}{200 \mu \mathrm{g} / \mathrm{g}}=0.15$ \\
Pig & $\frac{501 \mu \mathrm{g} / \mathrm{g} \times 0.04 \mathrm{~g} / \mathrm{g}}{200 \mu \mathrm{g} / \mathrm{g}}=0.1$ \\
Cat & $\frac{501 \mu \mathrm{g} / \mathrm{g} \times 0.07 \mathrm{~g} / \mathrm{g}}{200 \mu \mathrm{g} / \mathrm{g}}$ & $=0.18$ \\
\hline
\end{tabular}

pyrethrins is 0.002 , well below the level of concern for endangered species (Table XIII). RQs were similarly calculated for dog, cat, and pig using the oral $\mathrm{LD}_{50}$ values for the rat, $200 \mathrm{mg} / \mathrm{kg}$ (28) and literature referenced consumption rates for dog, cat, and pig (29). The resulting RQs ranged from 0.1 to 0.18 indicating that the potential secondary hazards for these species are minimal.

The same procedure was used to calculate RQs for rotenone and propoxur. The

Table XII. Risk Quotient Values and Associated Concerns

\begin{tabular}{|c|c|}
\hline$R Q$ Value & Associated Risk \\
\hline$<0.1$ & Use presents acceptable risk for use under approved guidelines \\
\hline$>0.1$ & Use restrictions may be imposed to protect endangered species \\
\hline$>0.2$ & $\begin{array}{l}\text { Use may be restricted to certified applicators and/or mitigation } \\
\text { techniques may be imposed }\end{array}$ \\
\hline$>0.5$ & $\begin{array}{l}\text { Mitigation techniques will be imposed to protect all species of } \\
\text { the same taxonomic order }\end{array}$ \\
\hline
\end{tabular}

resulting RQs are summarized in Table XIV. For rotenone, the highest snake residue concentration of $61 \mu \mathrm{g} / \mathrm{g}$ was utilized. For crow, acute toxicity was estimated with the $\mathrm{LC}_{50}(1608 \mu \mathrm{g} / \mathrm{g})$ from ring-necked pheasant (29) to give an RQ of 0.003 . For dog, pig, and cat, no rotenone LD50s were available, so the LD50 for the rat (60 mg/kg) was used. The resulting RQs for the dog, pig and cat are 0.06, 0.04, and 0.07. These risk quotients suggest that the secondary hazards associated with the use of rotenone to control brown tree snakes on Guam are minimal.

To calculate the RQs associated with the use of propoxur, the highest tissue residue concentration of $141 \mu \mathrm{g} / \mathrm{g}$ was used. For crow, $\mathrm{LC}_{50}$ for the house finch, 3.55 $\mathrm{mg} / \mathrm{kg}$ was used (EPA data base). For dog, pig, and cat, the rat oral $\mathrm{LD}_{50}$ of $41 \mathrm{mg} / \mathrm{kg}$ was used (RTECS)]. The resulting propoxur RQs ranged from 0.14 to 0.24 for mammals and 3.0 for the crow. The RQ of 3.0 for the crow triggers significant concern for secondary hazards, especially when an endangered species is potentially exposed.

Table XIV. Risk Quotients for Oral Dosing

\begin{tabular}{lllll}
\hline Toxicant & Crow & Pig & Dog & Cat \\
\hline Pyrethrin & 0.002 & 0.1 & 0.15 & 0.18 \\
Rotenone & 0.003 & 0.04 & 0.06 & 0.07 \\
Propoxur & 3.0 & 0.14 & 0.21 & 0.24 \\
\hline
\end{tabular}

Risk Quotients were also calculated using the highest rotenone concentration found in snakes dermally dosed at 10 and $20 \mathrm{mg} / \mathrm{kg}$ (Table XV). The resulting risk quotients were quite low for all species of concern, especially the crow. These data suggest that secondary hazards associated with dermal rotenone dosing to control brown tree snakes on Guam are minimal. 
Table XV. Rotenone Dermal Risk Quotients

\begin{tabular}{clc}
\hline & \multicolumn{2}{c}{$R Q$} \\
\hline Animal & $10 \mathrm{mg} / \mathrm{kg}$ & $20 \mathrm{mg} / \mathrm{kg}$ \\
\hline Crow & 0.0002 & 0.0004 \\
Dog & 0.005 & 0.01 \\
Pig & 0.05 & 0.1 \\
Cat & 0.005 & 0.01 \\
\hline
\end{tabular}

\section{Conclusions}

When administered orally in solutions, the acute toxicity of the potential brown tree snake toxicants evaluated was rotenone $>$ propoxur $=$ pyrethrins. Incorporation of the pesticides into biological matrices (SPAM or quail chicks) reduced the acute toxicity of all the pesticides. The greatest reduction was noted for rotenone. When administered in fortified baits, the toxicity was propoxur $>$ pyrethrins $>$ rotenone. With respect to secondary hazards, the most favorable (least risk, lowest RQ) compound appears to be rotenone followed by pyrethrum. Secondary hazards associated with propoxur appear to be manageable for mammalian scavengers, but suggest high risk for birds.

Acute toxicity for the pesticides when administered in solutions via dermal application was rotenone $>$ pyrethrins $=$ propoxur. Acute toxicity of dermally applied pesticides was about half to one quarter of that observed for gavage. However, pesticide residues and associated secondary hazard risk quotients were significantly less for dermal application.

From a secondary hazard perspective, dermal application of rotenone appears to be a promising technique for the control of brown tree snakes on Guam. However, the development of an efficient and selective dermal application procedure for the brown tree snake is not available. Based on our findings with these toxicants, oral dosing in biological based baits appears to be a less promising approach due to decreased toxicity noted when the toxicant was combined with the bait matrix. However, in the absence of the biological matrix, oral application of rotenone is highly toxic to brown tree snakes. We are currently attempting to capitalize on these observations by developing a synthetic lure which will combine a brown tree snake attractant into a synthetic matrix that will not decrease the toxicity of the pesticides. If successful, a toxicant such as rotenone could be combined with the synthetic matrix to produce an efficacious oral bait for reducing brown tree snake populations. At this point, subsequent reevaluation of residues and risk quotients may be needed. Further work is being conducted to identify additional compounds with high toxicity to brown tree snakes, minimal secondary hazards to non-target species, and adequate efficacy when incorporated into biological matrices.

\section{References}

1. Rodda G.H.; Sawai, Y; Cjozaar. D., Tanaka, H. Problem Snake Management, The Habu and the Brown Treesnake. Comstock Publishing Associates: Ithica, N.Y. 1999; pp 44.

2. Kinghorn, J.R. The Snakes of Australia. Revised Edition. Halstead Press: Sydney, Australia. 1964, 197 pp.

3. Fritts, T.H. Elapio. 1997, 47, 17-18.Rodda G.H.; Sawai, Y; Cjozaar. D., Tanaka, H. Problem Snake Management, The Habu and the Brown Treesnake. Comstock Publishing Associates: Ithica, N.Y. 1999; pp 236.

4. Rodda, G.H., Fritts, T.H., Conry, P.J. Pacific Science 1992, 46, 46-57.

5. Savidge, J.A. J. Herpetol. 1988 22, 275-282.

6. Fritts, T.H. and McCoid, M.J. The Snake. 1991, 23, 75-80.

7. Fritts, T.H.; Scott, N.J.; Savidge, J.A. The Snake. 1987, 19, 51-58.

8. Savidge, J.A. Ecology. 1987, 660-668.

9. National Research Council. The Scientific Basis for Preservation of the Mariana Crow National Academy Press: Washington, D.C. 1997. p. 18.

10. Aguan, C. Division of Aquatic and Wildlife Resources, Guam Department of Agriculture. personal communication, 1999.

11. McCoid and Stinson, 1991.

12. McCoid, M.J., Fritts, T.H., Campbell, E.W. The Texas Journal of Science 1994, 46, 365-368.

13. Brooks, J.E., Savarie, P.J. and Johnston, J.J. Wildlife Research. 1998, 25, 427435. Brooks, J.E.; Savarie, P.J.; Johnston, J.J.. Laboratory and Field Evaluation of Oral Toxicants for Brown Tree Snake Control (QA 484), Unpublished progress report, USDA/APHIS/WS/NWRC, 1996, 9 pp.

14. Sterner, R.T. and Mauldin, R.E. Arch. Environ. Contam. Toxicol. 1995, 28, 516523.

15. Primus, T.M.; Tawara, J.N.; Goodall, M.J.; Brooks, J.E.; Savarie P.J.; Johnston, J.J. J. Agric. Food Chem. 1998, 46, 2647-2650.

16. Johnston, J.J.; Furcolow, C.A.; Volz, S.A.; Mauldin, R.E.; Primus, T.M.; Savarie, P.J.; Brooks, J.E. J. Chromatogr. Sci. 1999, 37, 5-10.

17. Mauldin, R.E.; Johnston, J.J. J. Agric. Food Chem. (In Press)

18. Furcolow, C.E. Pyrethrin Residues in Whole Body Brown Tree Snakes (QA 490) 97-014. Unpublished analytical services report. USDA/APHIS/WS/ NWRC, 1997, 5pp.

19. Furcolow, C.E. Pyrethrin Residues in Whole Body Brown Tree Snakes (QA 484) 97-018. Unpublished analytical services report. USDA/APHIS/WS/ NWRC, 1997, 5pp. 
20. Furcolow, C.E.; Mauldin, R.E. Whole Body Residues in Brown Tree Snakes (QA 484, 490) 97-123. Unpublished analytical services report. USDA/APHIS/ WS/NWRC, 1998, 6pp.

21. Goodall, M.J. Whole Body Propoxur Residues in Brown Tree Snakes (QA 490) 96-065. Unpublished analytical services report. USDA/APHIS/WS/NWRC, 1996, 2pp.

22. Goodall, M.J.; Whole Body Propoxur Residues in Brown Tree Snakes (QA 490) 96-066. Unpublished analytical services report. USDA/APHIS/WS/NWRC, $1996,4 \mathrm{pp}$.

23. Baker, R.H. The avifauna of Micronesia, its origin, evolution, and distribution. University of Kansas Publications: Lawrence, KS, 1951; p. 359.

24. Urban, D.J.; Cook, N.J. Ecological Risk Assessment: Standard Evaluation Procedure of the Hazard Evaluation Division; U.S. Environmental Protection Agency. Office of Pesticide Programs. U.S. Government Printing Office: Washington, DC, 1986; EPA-540/9-85-001.

25. National Research Council. Risk Assessment in Federal Government: Managing to Process; U.S. Government Printing Office: Washington, DC; NASNRC Publ. 1983.

26. U.S. Environmental Protection Agency, Office of Research and Development. Wildlife Exposure Handbook. 1993; pp 3-5.

27. National Institute of Occupational Safety and Health. Registry of Toxic Effects of Chemical Substances (RTECS) Database. July, 1999.

28. Guide to the Care and Use of Experimental Animals. Canadian Council on Animal Care: Ottawa, Canada. Volume 1, 1984.

29. U.S. Environmental Protection Agency. Office of Pesticide Program Ecotoxicity Data Base.

\section{Acknowledgements}

The authors wish to acknowledge the critical support of the United States Department of Defense Legacy Program for funding NWRC brown tree snake research and Dr. Richard Bruggers, Assistant Director, NWRC for coordination of the NWRC brown tree snake research. Mention of specific products is for identification purposes only and does not constitute endorsement by USDA. 